\title{
PENGARUH TERAPI RENDAM KAKI AIR HANGAT DAN MASSAGE TERHADAP KUALITAS TIDUR KOMUNITAS LANSIA DI KELURAHAN TUNJUNGSEKAR
}

\author{
Liyana Nurul Azmi*, Nungki Marlian Yuliadarwati, Kurnia Putri Utami
}

Departement Fisioterapi, Universitas Muhammadiyah Malang, Jalan Bandung No. 1Malang 65133

*Corresponding author: liyananurulazmi@gmail.com

\begin{abstract}
ABSTRAK
Kualitas tidur merupakan respon tubuh yang menandakan status kesehatan pada lansia, kualitas tidur yang buruk dapat menimbulkan permasalah baik secara fisiologis maupun psikologis. Rendam kaki air hangat dan massage adalah salah satu intervensi untuk menangani kualitas tidur pada lansia. Penelitian ini bertujuan untuk mengetahui terapi rendam kaki air hangat dan massage terhadap kualitas tidur komunitas lansia di Kelurahan Tunjungsekar. Desain penelitian in adalah pre experiment one group pretest-posttest design. Responden dalam penelitian ini berjumlah 15 orang yang berada di Kelurahan Tunjungsekar. Dengan teknik purposive sampling menggunakan skala pengukuran kualitas tidur Pittsburgh Sleep Quality Index (PSQI). Hasil penelitian membuktikan adanya pengaruh yang signifikan sebelum dan sesudah diberikan intervensi terapi sendam kaki air hangat dan massage terhadap kualitas tidur lansia dengan menggunakan uji paired t-test didapatkan hasil nilai signifikasi $0,000(\mathrm{P}<0,05)$ yang berarti $\mathrm{H}_{0}$ ditolak dan $\mathrm{H}_{1}$ diterima. Terdapat pengaruh terapi rendam kaki air hangat dan massage terhadap kualitas tidur komunitas lansia di Kelurahan Tunjungsekar.
\end{abstract}

Keywords: Lansia, Rendam Kaki Air, Massage, Kualitas Tidur, Lansia

\section{PENDAHULUAN}

Sehat adalah suatu kebutuhan dan kondisi yang ingin dimiliki setiap manusia. Hal ini sejalan dengan Undang-Undang Republik Indonesia no. 36 tahun 2009 kesehatan merupakan keadaan sehat secara mental, fisik, spiritual maupun sosial yang memungkinkan seseorang dapat hidup produktif baik secara sosial maupun ekonomis. Menurut WHO, kesehatan adalah suatu kondisi dinamis yang meliputi kesehatan sosial, jasmani, rohani dan tidak hanya sebatas dari cacat, kelemahan dan penyakit (Adliyani, 2015).

Kualitas tidur ialah keadaan saat individu tidur dan pada saat bangun menghasilkan kondisi bugar dan segar
(Khasanah \& Hidayati, 2012). Kualitas tidur yang baik tidak memperlihatkan perasaan lelah, gelisah, apatis, lesu, kehitaman di area sekitar mata dan bengkak dikelopak mata, mata perih dan konjungtivitas merah, tidak fokus, sakit kepala, sering menguap dan mengantuk (Rumidin, Harianto, \& Rahayu, 2017). Setiap orang membutuhkan waktu tidur sekitar enam sampai delapan jam sehari. Kualitas tidur melibatkan dua fase yakni REM dan NREM. Pada fase REM (Rapid Eye Movement) ditandai dengan gerakan bola mata cepat, sedangkan fase NREM (Non Rapid Eye Movement) ditandai dengan gerakan bola mata lambat. Saat tidur seseorang mengalami NREM 4 tahap. 
Tahap 1 dan 2 adalah tidur dangkal dan seseorang akan mudah terbangun. Tahap 3 dan 4 merupakan tidur dalam dan seseorang akan sulit dibangunkan. Umumnya lansia akan mengalami penurunan tahap NREM 3 dan 4. Hal ini diakibatkan karena penurunan jumlah neuron dan fungsi neurotransmitter, terkait perubahan usia dalam siklus tidur-terjaga (Khasanah \& Hidayati, 2012).

Lansia di Indonesia merupakan kelompok dengan prevalensi gangguan tidur terbanyak, yaitu sekitar $67 \%$. Jawa Timur termasuk daerah yang memiliki penduduk lansia dengan presentasi yang tinggi. Berdasarkan proyeksi data dari badan pusat statistik provinsi Jawa Timur presentasi lansia di Jawa Timur tahun 2019 diperkirakan sekitar 12,25\%. Sedangkan lansia di Kota Malang sekitar 10,68\% (BPS, 2015). Penelitian yang dilakukan Rumidin menunjukkan bahwa $41,3 \%$ lansia di Kota Malang memiliki kualitas tidur yang buruk (Rumidin et al., 2017).

Penanganan untuk kualitas tidur yang buruk dapat dilakukan dengan dua cara, yakni farmakologi dan nonfarmakologi. Farmakologi adalah cara yang menggunakan media obat-obatan untuk merangsang penderita tertidur seperti zolpidem, tradozon, lozepram, diazepam dan amitripilin (Ariani \& Suryanti, 2019). Non farmakologi merupakan suatu metode alternatif yang tidak menggunakan obat-obatan sebagai media penyembuhannya. Pada pelaksanaannya non farmakologi dapat dilakukan dengan beberapa cara seperti terapi, senam dan olahraga sehingga badan menjadi rileks (Subandi, 2017).

Terapi relaksasi yang umum digunakan untuk mengatasi kualitas tidur buruk adalah dengan merendam kaki pada air hangat. Air hangat dapat memberikan efek relaksasi karena terjadi penurunan ketegangan otot akibat meregangnya sel- sel pada otot dan pelebaran pembuluh darah yang dapat meningkatkan suplai nutrisi dan oksigen kedalam jaringan. Pada sistem endokrin air hangat dapat menstimulus hormon serotonin yang kemudian diubah menjadi melatonin, yakni hormon yang menimbulkan kondisi mengantuk serta rileks pada tubuh (Putra, 2017). Merendam kaki pada air yang memiliki temperatur $37^{\circ} \mathrm{C}-39^{\circ} \mathrm{C}$ selama 10 menit sampai betis bermanfaat untuk mengurangi kontraksi otot sehingga menimbulkan perasaan rileks yang dapat mengatasi masalah tidur (Permady, 2015).

Kualitas tidur buruk pada lansia selanjutnya juga dapat diatasi dengan memberikan terapi massage. Terapi massage ini menggunakan tangan untuk merelaksasi, mengurangi stres, serta memberikan kenyamanan saat tidur dan mengurangi kecemasan (Dionesia, 2017). Massage sebelum tidur dapat mempercepat proses tidur dengan beberapa mekanisme yaitu dengan stimulasi morpin endogen seperti endorfin, dinorfin dan enkifalin serta perannya dalam menimbulkan relaksasi otot. Pemberian massage khususnya pada area kaki dapat melancarkan sistem peredaran darah. Massage dapat merangsang sistem saraf dan meningkatkan aktifitas otot sehingga pijatan pada kaki dapat merelaksasi otototot yang memberikan efek sedatif (Ariani \& Suryanti, 2019).

Berdasarkan hasil studi pendahuluan yang telah peneliti lakukan dengan melakukan wawancara dan pengisian quisioner PSQI pada komunitas lansia di Kelurahan Tunjungsekar diperoleh hasil beberapa lansia memiliki kualitas tidur yang buruk. Kebanyakan lansia tidak menyadari bahwa mereka memiliki kualitas tidur yang buruk, sehingga mereka juga tidak memahami bagaimana cara memperbaiki kualitas tidur yang buruk. Karena itu peneliti ingin memberikan intervensi untuk 
membuktikan bahwa dengan merendam kaki menggunakan air hangat dan massage dapat memberikan manfaat terutama meningkatkan kualitas tidur.

\section{METODE}

Desain penelitian ini menggunakan desain pre-experimental dengan rancangan penelitian one grup pretest-post test design yang akan mempelajari tentang pengaruh antara variabel independen (terapi rendam kaki air hangat dan massage) dan variabel dependen (kualitas tidur). Sampel yang memenuhi kriteria inklusi dalam penelitian ini sebanyak 15 orang, dengan instrumen penelitian menggunakan kuesioner Pittsburgh Sleep Quality Index (PSQI) sebagai alat ukur kualitas tidur. uji normalitas dan hipotesis yang digunakan dalam penelitian ini adalah Uji ShapiroWilk dan Uji Paired t-Test.

\section{HASIL PENELITIAN}

1. Karakteristik Responden Berdasarkan Usia

Karakteristik responden berdasarkan umur adalah sebagai berikut:

Tabel 1 Karakteristik Berdasarkan Umur

\begin{tabular}{cccc}
\hline No. & $\begin{array}{c}\text { Umur } \\
\text { (Tahun) }\end{array}$ & Frekuensi & $\begin{array}{c}\text { Presentase } \\
(\boldsymbol{\%})\end{array}$ \\
\hline 1. & $60-74$ & 10 & 66,7 \\
2. & $75-90$ & 5 & 33,3 \\
\hline \hline & Total & $\mathbf{1 5}$ & $\mathbf{1 0 0}$ \\
\hline
\end{tabular}

Pada tabel 1 dapat diketahui lansia yang berumur 60-74 tahun sebanyak 10 responden dengan presentase $(66,7 \%)$ dan lansia yang berumur 75 90 tahun sebanyak 5 responden presentase (33,3\%). Dapat disimpulkan bahwa responden terbanyak pada umur 60-74 tahun.

2. Karakteristik Responden Berdasarkan Jenis Kelamin

Karakteristik responden berdasarkan jenis kelamin pada tabel 2 adalah sebagai berikut:
Tabel 2 Karakteristik Berdasarkan Jenis Kelamin

\begin{tabular}{llcc}
\hline No. & $\begin{array}{c}\text { Jenis } \\
\text { Kelamin }\end{array}$ & Frekuensi & $\begin{array}{c}\text { Presentase } \\
(\mathbf{\%})\end{array}$ \\
\hline 1. & Laki-laki & 4 & 26,7 \\
2. & Perempuan & 11 & 73,3 \\
\hline \hline & Total & $\mathbf{1 5}$ & $\mathbf{1 0 0}$ \\
\hline
\end{tabular}

Pada tabel di atas dapat diketahui bahwa lansia dengan jenis kelamin laki-laki sebanyak 4 responden $(26,7 \%)$ dan jenis kelamin perempuan sebanyak 13 responden (73,3\%). Dapat disimpulkan pada penelitian ini jenis kelamin terbanyak adalah perempuan.

3. Karakteristik Responden Berdarkan Pekerjaan

Karakteristik berdasarkan pekerjaan responden dapat dilihat pada tabel 3 sebagai berikut:

Tabel 3 Karakteristik Berdasarkan Pekerjaan

\begin{tabular}{lccc}
\hline No. & Pekerjaan & Frekuensi & $\begin{array}{c}\text { Presentase } \\
(\boldsymbol{\%})\end{array}$ \\
\hline 1. & Guru & 1 & 6,7 \\
2. & IRT & 9 & 60 \\
3. & Pensiunan & 5 & 33,3 \\
\hline \hline & Total & $\mathbf{1 5}$ & $\mathbf{1 0 0}$ \\
\hline
\end{tabular}

Dapat diketahui bahwa responden dengan pekerjaan Guru sebanyak 1 orang $(6,7 \%)$, pekerjaan Ibu Rumah Tangga atau IRT sebanyak 9 responden dengan presentase $(60 \%)$ dan pensiunan sebanyak 5 responden $(33,3 \%)$. Penelitian ini menunjukkan bahwa lansia terbanyak memiliki pekerjaan sebagai Ibu Rumah Tangga.

4. Karakteritisk Responden Sebelun Dan Sesudah Terapi Rendam Kaki Air Hangat Dan Massage

Pada tabel 4 dapat diketahui bahwa sebelum terapi rendam kaki kaki air hangat dan massage terdapat 15 responden dengan presentase (100\%) mengalami kualitas tidur buruk, sedangkan pada tabel 5 setelah diberikan terapi rendam kaki air hangat 
dan massage terdapat 15 responden dengan presentase $(100 \%)$ mengalami kualitas tidur yang baik.

Tabel 4 Karakteristik Berdasarkan Tingkat Kualitas Tidur Sebelum Terapi Rendam Kaki Air Hangat dan Massage pada Lansia

\begin{tabular}{|c|c|c|c|c|}
\hline No. & $\begin{array}{c}\text { Tingkat } \\
\text { Kualitas } \\
\text { Tidur }\end{array}$ & Interval & Frekuensi & $\begin{array}{c}\text { Presentasi } \\
(\%)\end{array}$ \\
\hline 1. & $\begin{array}{l}\text { Kualitas } \\
\text { tidur baik }\end{array}$ & $\leq 5$ & 0 & 0 \\
\hline \multirow[t]{2}{*}{2.} & $\begin{array}{l}\text { Kualitas } \\
\text { tidur } \\
\text { buruk }\end{array}$ & $>5$ & 15 & 100 \\
\hline & Total & & 15 & 100 \\
\hline
\end{tabular}

Tabel 5 Karakteristik Berdasarkan Tingkat Kualitas Tidur Sesudah Terapi Rendam Kaki Air Hangat dan Massage pada Lansia

\begin{tabular}{cccc}
\hline $\begin{array}{c}\text { No. Tingkat } \\
\text { Kualitas } \\
\text { Tidur }\end{array}$ & Interval & Frekuensi & $\begin{array}{c}\text { Presentase } \\
(\%)\end{array}$ \\
\hline $\begin{array}{l}\text { 1. Kualitas } \\
\text { tidur baik }\end{array}$ & $\leq 5$ & 15 & 100 \\
$\begin{array}{c}\text { 2. Kualitas } \\
\text { tidur } \\
\text { buruk }\end{array}$ & $>5$ & 0 & 0 \\
\hline Total & & $\mathbf{1 5}$ & $\mathbf{1 0 0}$ \\
\hline
\end{tabular}

5. Uji Normalitas

Dalam Uji normalitas yang digunakan dalam penelitian ini adalah Shapir-Wilk sebagai berikut:

Tabel 6 Uji Normalitas Kualitas Tidur Lansia

\begin{tabular}{cccc}
\hline & \multicolumn{3}{c}{ Shapiro-Wilk } \\
\cline { 2 - 4 } Kelompok & Statistic & Df & Sig. \\
\hline Pre-test & .936 & 15 & .331 \\
Post-test & .932 & 15 & .293 \\
\hline Shapiro-Wilk: & Df $=$ Degree of & Freed
\end{tabular}

Shapiro-Wilk: $D f=$ Degree of Freedom (Derajat Kebebasan); Sig=Signifikasi

Dari data diatas didapatkan hasil Shapiro-Wilk dengan nilai signifikasi kelompok intervensi pre-test kualitas tidur yaitu 0,293 $(\mathrm{P}>0,05)$ dan post-test $0,331 \quad(\mathrm{P}>0,05)$, sehingga dapat disimpulkan bahwa data berdistribusi normal. Dikarenakan data berdistribusi normal maka uji hipotesa yang akan digunakan adalah uji paired t-test.

6. Uji Hipotesis

Dalam Uji hipotesis penelitian ini menggunakan Paired t-Test sebagai berikut:

Tabel 7 Uji Paired t-Test Kualiatas Tidur

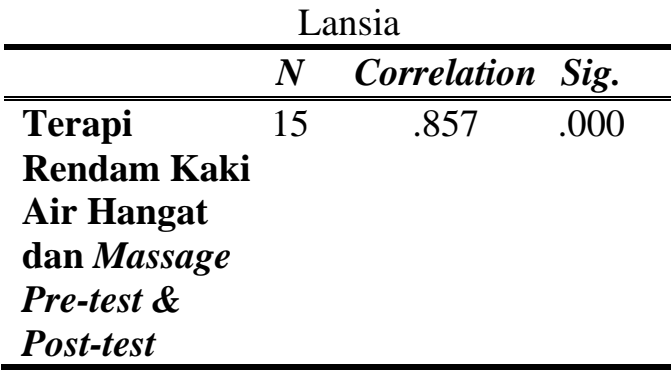

Paired t-Test: $N=$ Jumlah Responden;

Correlation $=$ Korelasi; Sig $=$ Signifikasi

Berdasarkan hasil uji paired t-test pada tabel 5.7 diperoleh nilai signifikasi sebesar 0,000 $(\mathrm{P}<0,05)$. Jadi dapat disimpulkan $\mathrm{H}_{1}$ diterima yaitu terdapat pengaruh pemberian terapi rendam kaki air hangat dan massage terhadapat kualitas tidur pada lansia di Kelurahan Tunjungsekar

\section{PEMBAHASAN}

Hasil analisa data karakteristik berdasarkan umur responden berjumlah 15 orang lansia pada komunitas lansia di Kelurahan Tunjungsekar, dengan responden terbanyak berumur 60-74 tahun. Hasil penelitian tersebut menandakan bahwa semakin bertambahnya umur seseorang memiliki pengaruh terhadap kualitas tidur. Lansia cenderung memiliki kualitas tidur yang buruk dan durasi tidur yang berkurang dibandingkan ketika masa muda (Azizah, 2011). Kualitas tidur yang buruk terjadi akibat perubahan pola tidur karena beberapa faktor dan proses patologis (Manurung \& Adriani, 2017).

Pada lansia terjadi penurunan pada tidur NREM tahap 3 dan 4, sementara terjadi peningkatan pada tahap 1 dan 2 sehingga tidur menjadi kurang efisien. Perubahan pada sistem saraf pusat yang mengurangi sensitifitas terhadap irama sirakandian menimbulkan gangguan siklus 
tidur dan terjaga (Nana, 2017). Penyakit fisik yang dialami lansia juga dapat menganggu kualitas tidur seperti nyeri sendi, osteoporosis, parkinson dan penyakit lainnya (Khasanah \& Hidayati, 2012). Proses penuaan pada lansia yang mengakibatkan penurunan kemampuan fisik maupun mental sehingga tidak produktif lagi dan mengalami beberapa masalah kesehatan salah satunya penurunan kualitas tidur (Prananto, 2016).

Dari hasil pengelompokan karakteristik responden berdasarkan jenis kelamin pada komunitas lansia di Kelurahan Tunjungsekar menunjukkan bahwa responden perempuan lebih mendominasi. Frekuensi lansia mengalami kualitas tidur buruk dengan jenis kelamin perempuan lebih tinggi dari laki-laki (Subandi, 2017). Pada perempuan saat memasuki usia lanjut terjadi penurunan pada hormon progesteron dan esterogen yang mempunyai reseptor dihipotalamus, sehingga terjadi perubahan pada irama sirkadian dan pola tidur secara langsung (Khasanah \& Hidayati, 2012). Aksis hipotalamus-hipofisis-adrenal (HPA) yang lebih aktif dan pelepasan hormon pertumbuhan (GHRH) yang lebih sedikit pada perempuan meningkatkan resiko kualitas tidur buruk (Kimura, 2005). Perempuan juga cenderung lebih cemas karena lebih sensitif sedangkan laki-laki cenderung aktif dan eksploratif (Dionesia, 2017).

Hasil pengelompokan karakteristik reponden berdasarakan perkerjaan dapat diketahui bahwa pekerjaan responden terbanyak adalah Ibu Rumah Tangga yang berjumlah 9 orang. Hal ini dapat disimpulkan bahwa distribusi frekuensi pekerjaan responden sebagian besar tidak bekerja. Pekerjaan merupakan salah satu faktor sosiokultural yang dapat mempengaruhi kualitas tidur seseorang (Prananto, 2016). Faktor-faktor yang mempengaruhi kualitas tidur salah satunya adalah faktor gaya hidup dan stress emosional. Rutinitas atau gaya hidup harian juga dapat mempegaruhi pola tidur sesorang yang meliputi kerja berat, aktivitas pada larut malam dan perubahan jadwal tidur (Havisa, 2014). Level aktivitas dalam keseharian yang terlalu berat dan menumpuk maka akan mempengaruhi pola tidur, tidur yang dialami seseorang akan semakin nyenyak apabila tingkat kelelahan semaki tinggi dan akan memper periode tidur NREM (Permady, 2015). Ibu rumah tangga mudah mengalami kualitas tidur buruk karena merasa kesepian mulai ditinggalkan anak dan suami, tidak melakukan aktivitas berat sehingga tidak merasa kelehahan yang membuat cepat tertidur. Pada pensiunan terjadi perubahan aktivitas yang awalnya aktif bekerja akan cepat merasakan kelelahan dan capek sehingga kebutuhan istirahat meningkat, tetapi semenjak pensiun terjadi penurunan aktivitas dan memiliki waktu istirahat yang lebih banyak (Diahuputri, 2017).

Hasil analisa data pada penelitian ini dapat diketahui bahwa setelah diberikan intervensi berupa terapi rendam kaki air hangat selama 10 menit dan massage selama 10 menit saat malam hari pada lansia yang memiliki kualitas tidur buruk terjadi perubahan pada semua responden. Hasil penelitian ini sesusai dengan penelitian yang dilakukan wibowo (2019) dalam penelitiannya pengaruh rendam kaki air hangat terhadap kualitas tidur pada lansia menunjukkan bahwa terdapat peningkatan kualitas tidur pada lansia setelah diberikan terapi rendam kaki air hangat. Terapi rendam kaki air hangat dan massage dapat membuat otot menjadi relaks, meningkatkan aliran darah, mengurangi nyeri, meningkatkan sekresi hormon endogen dan penurunan hormon simpatik. Lansia merasakan relaksasi dan 
memiliki keinginan untuk tidur setelah diberikan terapi rendam kaki air hangat dan massage sehingga dapat meningkatkan kualitas tidur (Wibowo \& Purnamasari, 2019).

Merendam kaki dengan air hangat merupakan suatu metode yang efektif berupa pemberian aplikasi panas pada tubuh untuk mengurangi rasa tidak nyaman. Merendam kaki dengan air hangat yang bertemperatur $37^{\circ} \mathrm{C}-39^{\circ} \mathrm{C}$ selama 10 menit bermanfaat untuk menekan saraf simpatis yang memberikan efek relaksasi sehingga aktivitas saraf parasimpatis lebih berperan dan aktif (rest and digest) (Dionesia, 2017). Peningkatan kualitas tidur terjadi akibat mekanisme saraf pada daerah kaki terutama dikulit yaitu plexus venosus dari rangkaian saraf ini stimulasi diteruskan ke cornu posterior kemudian dilanjutkan ke medulla spinalis, setelah itu diteruskan ke lamina I, II, III, radix dorsalis, kemudian dilanjutkan ke ventrobasal thalamus dan masuk gerbang otak tepatnya di daerah rafe bagian bawah pons dan medula, sehingga timbul efek soparifik (efek ingin tidur) (Prananto, 2016). Relaksasi juga mempengaruhi respon tubuh seperti pembuluh darah kulit membesar, penurunan ketegangan otot rangka, penurunan asam laktat, penurunan kadar epineprin dan meningkatkatnya sekresi hormon melantonin (Permady, 2015).

Pada penelitian Subandi (2017) menyatakan bahwa relaksasi efektif terhadap peningkatan kualitas tidur. Massage dapat memberikan dampak pada peningkatan sirkulasi darah, memperbaiki sifat otot dan memberikan efek relaksasi (Afianti \& Mardhiyah, 2017). Mekanisme massage pada kaki terhadap kualitas tidur tejadi ketika masssage memberikan rangsang tekan pada saraf kaki. Rangsangan bioelektrik tersebut dapat melancarkan cairan dalam tubuh yang bertugas untuk menyalurkan nutrisi dan melancarkan sirkulasi darah serta oksigen ke sel-sel pada tubuh sehingga akan menimbulkan efek relaksasi. Rectingular Activating System (RAS) yang berada di batang otak akan mengalami penurunan akibat efek rileks yang ditimbulkan, sehingga sistem kerja akan diambil alih oleh batang otak lain yang disebut Bulbar Synchronizing Region (BSR). BSR memiliki tugas untuk melepaskan serotonin yang dapat menimbulkan efek mengantuk sehingga dapat meningkatkan kualitas tidur seseorang (Pramesti et al, 2019).

\section{KESIMPULAN}

Terapi rendam kaki air hangat (10 menit) dan massage (10 menit) yang dilakukan 7 kali berturut-turut selama satu minggu saat malam hari dapat meningkatkan kualitas tidur pada komunitas lansia di Kelurahan Tunjungsekar

\section{REFERENCES}

Adliyani, Za. O. N. (2015). Pengaruh Perilaku Individu terhadap Hidup Sehat The Effect of Human Behavior for Healthy Life. Majority, 4(7), 109114.

Afianti, N., \& Mardhiyah, A. (2017). Pengaruh Foot Massage terhadap Kualitas Tidur Pasien di Ruang ICU. Jurnal Keperawatan Padjadjaran, 5(1), 86-97. https://doi.org/10.24198/jkp.v5n1.10

Ariani, D., \& Suryanti. (2019). Pengaruh foot massage terhadap kualitas tidur pada lansia di panti wredha dhara bakti kasih surakata. Jurnal Terpadu Ilmu Kesehatan, 8(1), 87-93.

Azizah, L. M. R. (2011). Keperawatn Lanjut Usia. Yogyakarta: Graha Ilmu.

Diahuputri, N. M. N. (2017). Efektivitas Pemberian Progressive Muscle Relaxation Dibandingkan Aromatherapy Massage Untuk Meningkatkan Kualitas Tidur Pada Pekerja Perempuan Di Rumah Sakit Bali Royal Denpasar. 
Dionesia, E. A. (2017). Perbedaan Efektifitas Tindakan Massage Dan Pemberian Rendam Air Hangat Dalam Memenuhi Kualitas Tidur Pada Lansia. Jrkn, 1(2), 111-118.

Havisa, R. (2014). Hubungan Kualitas Tidur dengan Tekanan Darah Pada Usia Lanjut di Posyandu Lansia Dusun Jelapan Sindumartani Ngemplak Sleman Yogyakarta. Vitamins, 62(10), 1-18.

Khasanah, K., \& Hidayati, W. (2012). Kualitas Tidur Lansia Balai Rehabilitasi Sosial "MANDIRI " Semarang. Jurnal Nursing Studies, 1(1), 189-196. Diambil dari http://ejournals1.undip.ac.id/index.php/jnursing

Kimura, M. (2005). Minireview: Genderspecific sleep regulation. Sleep and Biological Rhythms, 3(2), 75-79. https://doi.org/10.1111/j.14798425.2005.00168.x

Manurung, R., \& Adriani, T. U. (2017). Pengaruh Terapi Relaksasi Otot Progresif Terhadap Kualitas Tidur pada Lansia di Panti Jompo Yayasan Guna Budi Bakti Medan Tahun 2017. Jurnal Ilmiah Keperawatan IMELDA, 3(2), 294-306.

Nana, R. de L. (2017). Pengaruh Terapi Rendam Kaki Air Hangat Terhadap Kualitas Tidur Lansia di Rumah Usiawan Panti Surya Surabaya.

Permady, G. G. (2015). Pengaruh merendam kaki dengan air hangat terhadap kualitas tidur lansia di wilayah kerja puskesmas astanalanggar kecamatan losari cirebon jawa barat. In Skripsi Program Studi Ilmu Keperawatan Fakultas Kedokteran dan Ilmu Kesehatan Universitas Islam Negeri Syarif Hidayatullah Jakarta.

Pramesti, T. A., Indriani, N. W. N., Trisnadewi, N. W., \& Juliawan, D. G. (2019). Pengaruh Foot Massage Terhadap Kualitas Tidur Pada Lansia. 215-223.

Prananto, A. E. (2016). Pengaruh Massage
Kaki dan Rendam Air Hangat Pada Kaki Terhadap Penurunan Insomnia Pada Lansia. Diambil dari http://eprints.ums.ac.id/44311/11/NA SKAH PUBLIKASI.pdf

Putra, I. D. (2017). Pengaruh Rendaman Air Hangat Pada Kaki. (06), 12-16.

Rumidin, Harianto, T., \& Rahayu, W. (2017). Hubungan Tingkat Umur Dengan Kualitas Tidur Pada Lansia Di Posyandu Permadi (Vol. 2). Diambil dari https://publikasi.unitri.ac.id/index.php /fikes/article/download/150/184\%0A

Subandi, E. (2017). Pengaruh Rendam Kaki Dengan Air Hangat Terhadap Kualitas Tidur Lansia Di Desa Pakusamben Kecamatan Babakan Kabupaten Cirebon. In Endang Subandi (Vol. 2).

Wibowo, D. A., \& Purnamasari, L. (2019). Pengaruh Rendam Kaki Air Hangat Terhadap Kualitas Tidur pada Lansia di Wilayah Kerja Puskesmas Handapherang. Jurnal Keperawatan Galuh, Vol. 1, hal. 104-123. Diambil dari https://jurnal.unigal.ac.id/index.php/J KG/article/view/2635 